\title{
New Synthetic Route to Granulatimide and Its Structural Analogues
}

\author{
Takuji Yoshida, Masakazu NishiYachi, Nobuyuki Nakashima, Masayuki Murase,* and \\ Eiichi KoTANI
}

Showa Pharmaceutical University; Machida, Tokyo 194-8543, Japan.

Received January 16, 2002; accepted February 28, 2002

\begin{abstract}
The Stille coupling reaction of stannylindole 12 with 4-iodoimidazole 13 (or 24) in the presence of $\mathrm{PdCl}_{2}\left(\mathrm{PPh}_{3}\right)_{2}$ gave the corresponding indole-imidazole coupling product 14 (or 25), thereby affording a new synthetic approach to the alkaloid granulatimide (7), isolated from the Brazilian ascidian Didemnum granulatum, as well as its structural analogues, 10-methylgranulatimide (23), 17-methylgranulatimide (30), 10,17-dimethylgranulatimide (31).
\end{abstract}

Key words alkaloid; indole; maleimide; imidazole; Stille coupling reaction; synthesis

Bisindolylmaleimides represent an important class of antitumor antibiotics. ${ }^{1,2)}$ Rebeccamycin (5), a weak inhibitor of topoisomerase I, and staurosporin (3), a non-specific protein kinase $\mathrm{C}(\mathrm{PKC})$ inhibitor, are representative compounds of this family.

It is noteworthy that, of two classes of G2 checkpoint inhibitors that have been discovered serendipitously, one class includes the purine alkaloids caffeine (1) and pentoxifylline $(2),{ }^{3-5)}$ while the other includes the bisindolylmaleimides staurosporine (3) and UCN-01 (4).

Recently it was reported that an extract of the Brazilian ascidian Didemnum granulatum showed strong activity as a G2 checkpoint inhibitor due to the presence of two compounds, granulatimide (7) and isogranulatimide $(8)^{6-9)}$ (Chart 1). These compounds lack the second indole unit of bisindolylmaleimides such as staurosporine (3) and UCN-01 (4), having an imidazole moiety in its place. The indole/maleimide/ imidazole-containing aromatic heterocyclic skeletons of 7 and $\mathbf{8}$ are without precedent among natural products, although they are related the purine alkaloids caffeine (1) and pentoxifylline (2).

Total syntheses of 7, 8 and related analogues have already been reported by several groups. ${ }^{6,10,11)}$

Recently, we reported the synthesis and protein kinase $\mathrm{C}$ inhibitory activity of arcyriacyanin A (6), ${ }^{12,13)}$ an unsymmetrically substituted green-blue indole pigment of the slime mould Arcyria obvelata ONSBERg (Arcyria nutans GREv.).

The method used to construct the unsymmetric bisindolylmaleimide employed the reaction of bisindolyl Grignard reagents with dibromomaleimides. Our strategy for the synthesis of granulatimide (7) and its analogues is illustrated in Chart 2. The application of our method for the synthesis of arcyriacyanin $\mathrm{A}^{13)}$ should allow the synthesis of 7 by reaction of the bromomagnesium salt of the indole-imidazole $\mathbf{1 0}$ with 3,4-dibromomaleimide.

We are interested in the syntheses and biological activities of indole maleimide compounds, and in this paper we would like to report a new synthetic route to granulatimide (7), 10methylgranulatimide (23), 17-methylgranulatimide (30) and 10,17-dimethylgranulatimide (31).

\section{Results and Discussion}

The new synthesis of 7 and its analogues consists of the Stille coupling reactions of stannylindole 12 with 4-iodo-1- (methoxymethyl)imidazole (13) ${ }^{14)}$ and 4-iodo-1-methylimidazole (24) ${ }^{15)}$ (Chart 3). The stannyl derivative 12 was itself prepared from 1-methoxyindole (11) by regioselective lithiation with $n$-BuLi and subsequent reaction with chlorotributylstannane. ${ }^{16)}$ The Stille coupling reaction of $\mathbf{1 2}$ with imidazoles such as $\mathbf{1 3}$ (or 24) in the presence of $\mathrm{PdCl}_{2}\left(\mathrm{PPh}_{3}\right)_{2}$ afforded the corresponding indole-imidazole coupling product 14 ( $48 \%$ yield) or $\mathbf{2 5}$ (58\% yield), respectively.

Subsequent deprotection of the 1-methoxy group in $\mathbf{1 4}$ and 25 was readily achieved with $\mathrm{Mg}$-methanol ${ }^{13)}$ in tetrahydrofuran (THF) to give, in 75 and $93 \%$ yields, $4-(1 H$-indol-2yl)-1-(methoxymethyl)-1H-imidazole (15) and 4-(1H-indol2-yl)-1-methyl-1 $H$-imidazole (26), a key intermediate for the syntheses of granulatimide and its analogues.

To confirm the coupling reaction, compounds $\mathbf{1 5}$ and $\mathbf{2 5}$ were subjected to heteronuclear multiple bond connectivity (HMBC) study. As shown in Fig. 1, 15 was demonstrated to be the $2,4^{\prime}$-coupling product, since a correlation between the methylene protons of the methoxymethyl (MOM) group and $\mathrm{C}\left(2^{\prime}\right)$ as well as $\mathrm{C}\left(5^{\prime}\right)$ was observed. The HMBC spectrum of $\mathbf{2 5}$ was similar to that of $\mathbf{1 5}$, except for the long-range correlation of methyl protons to $\left(\mathrm{C}^{\prime}\right)$ and $\left(\mathrm{C}^{\prime}\right)$.

The next stage in the syntheses of 7 and its analogues was carried out by the reaction of the maleimide 17 (or 18) with the Grignard reagent 16 (or 27) prepared from the coupling product $\mathbf{1 5}$ (or 26) according to our previous synthesis ${ }^{12,13)}$ with some modifications. The reaction of $\mathbf{1 5}$ (or 26) with ethylmagnesium bromide in absolute THF gave the $\mathrm{MgBr}$ salt 16 (or 27). The condensation of $\mathbf{1 6}$ (or 27) with maleimide 17 (or 18) in THF to afforded the corresponding synthon condensation product $(\mathbf{1 9}, \mathbf{2 0}, \mathbf{2 8}$, or $\mathbf{2 9})$ in a yield of 42,71 , 43 , or $68 \%$, respectively.

We have carried out the photocyclization of 19 (or 20) according to the Piers procedure ${ }^{10)}$ with some modification. Thus, when 19 (or 20) was irradiated with an external light source ( $60 \mathrm{~W}$, low-pressure mercury lamp) in $\mathrm{MeCN}$, we obtained the granulatimide derivative $\mathbf{2 1}$ or $\mathbf{2 2}$ in 80 or $96 \%$ yield, respectively. Deprotection of the MOM group was performed with $10 \% \mathrm{HCl}$ either on $\mathbf{2 1}$ or $\mathbf{2 2}$ (Chart 3). Granulatimide (7) and 10-methylgranulatimide 23 were obtained in 72 and $92 \%$ yields, respectively. All physical data for granulatimide (7) were identical with those reported. ${ }^{6)}$ The structural assigment of the new analogue $\mathbf{2 3}$ was based on the NMR spectrum and high resolution (HR)-MS. As expected, 
<smiles></smiles>

$1 \mathrm{H}=\mathrm{M}$

$2 \mathrm{~A}=\left(\mathrm{CH}_{2}\right)_{4} \mathrm{COM}$<smiles></smiles>

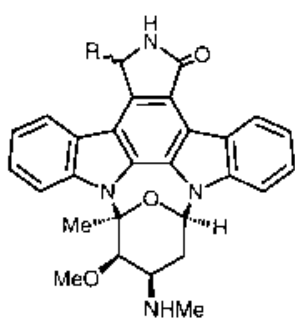

$3 \mathrm{~B}=\mathrm{H}$

$4 \mathrm{~F}=\mathrm{OH}$

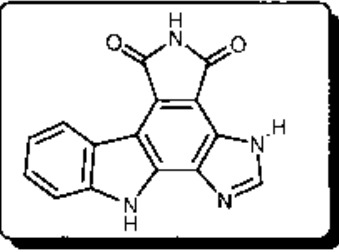

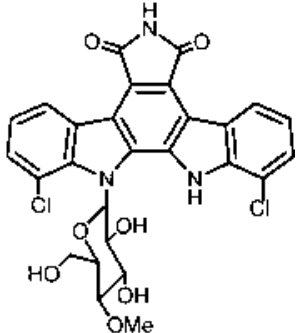

5<smiles>O=C1NC(=O)c2c1c1c3ccccc3[nH]c1n1cncc21</smiles>

Chart 1

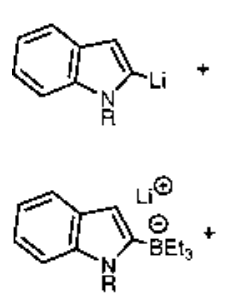<smiles>O=C1CCCc2[nH]ccc21</smiles><smiles>C=C[N+]#N</smiles><smiles>c1ccc2[nH]c(-c3ccc4c(c3)CCC4)cc2c1</smiles><smiles>O=C1NC(=O)C(Br)=C1Br</smiles>

Suzuki coupling

9

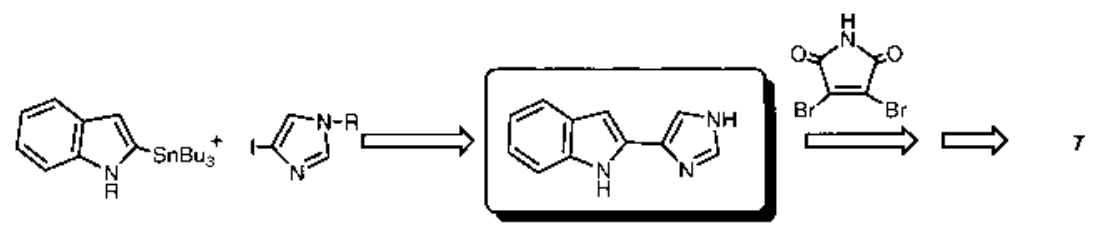

10

Chart 2

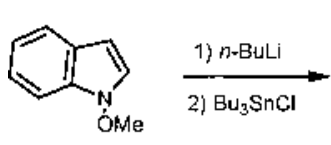<smiles>[R]n1cnc(-c2cc3ccccc3n2OC)c1</smiles>

$\left\{\begin{array}{l}14: \text { R. }=\text { MOM } \\ 25: \text { R. =Me }\end{array}\right.$

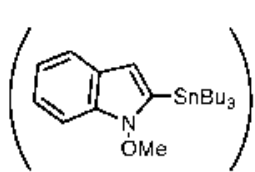

12

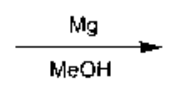

Chart 3

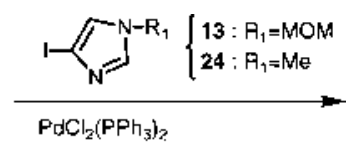<smiles>[R7]n1cnc(-c2cc3ccccc3[nH]2)c1</smiles>

$\left\{\begin{array}{l}15: A_{1}=M O M \\ 26: H_{1}=M e\end{array}\right.$ the ${ }^{1} \mathrm{H}-\mathrm{NMR}$ spectrum of $\mathbf{2 3}$ is very similar to that of granulatimide (7), except that the resonance due to the maleimide $N$-Me function in 23 ( $\delta$ 3.12) replaces the corresponding $\mathrm{N}-\mathrm{H}$ signal $(\delta 10.96)$ of 7 . Thus, a straightforward and effi- cient synthesis of granulatimide (7) and its analogue $\mathbf{2 3}$ has been developed.

We then turned to the syntheses of 17-methylgranulatimide (30) and 10,17-dimethylgranulatimide (31). A similar 
sequence of reactions to that described above for the preparation of granulatimide provided readly access to 17-methylgranulatimide (30) and 10,17-dimethylgranulatimide (31) from 28 and 29, via photocyclization ${ }^{6}$ in $\mathrm{MeCN}$, affording $\mathbf{3 0}$ and $\mathbf{3 1}$ in 50 and $70 \%$ yields, respectively. The synthetic 17-methylgranulatimide (30) was identical in all respects to synthetic products reported previously. ${ }^{10)}$ As expected, the ${ }^{1} \mathrm{H}-\mathrm{NMR}$ spectrum of $\mathbf{3 1}$ is very similar to that of 30, except that the resonance due to the maleimide $N$-Me function in $\mathbf{3 1}$ $(\delta 3.08)$ replaces the corresponding $\mathrm{N}-\mathrm{H}$ signal $(\delta 11.04)$ of 30. Furthermore, the ${ }^{1} \mathrm{H}-{ }^{1} \mathrm{H}$ and ${ }^{1} \mathrm{H}-{ }^{13} \mathrm{C}$ correlation spectroscopy (COSY) data substantiated the structure of 31. Consequently, this product was confirmed to be 10,17-dimethylgranulatimide (31). As anticipated, granulatimide (7) and its analogues 23, 30, and $\mathbf{3 1}$ are extremely insoluble in most common organic solvents.

Thus, a new synthetic route to granulatimide (7) and its analogues 23, 30, and $\mathbf{3 1}$ has been established by the construction of the indole-imidazole nucleus 15 (or 26) based on the Stille coupling reaction involving the indole-imidazole $\left(2,4^{\prime}-\right)$ bond. An evaluation of the biological activity of these materials will be reported elsewhere.

\section{Experimental}

All melting points ( $\mathrm{mp}$ ) were determined on a Yanagimoto micromelting point apparatus and are uncorrected. Infrared (IR) spectra were recorded with a JASCO IR-700 spectrometer. ${ }^{1} \mathrm{H}$ - and ${ }^{13} \mathrm{C}-\mathrm{NMR}$ spectra were obtained on JNM-AL300 and JMN- $\alpha 500$ spectrometers. The chemical shifts were given in ppm $(\delta)$ values with tetramethylsilane as an internal standard (DMSO- $d_{6}$ and $\mathrm{CDCl}_{3}$ ). Mass spectra were recorded on JEOL JMS-D300, JMS-HX110 and Shimadzu QP-5000 spectrometers. Wako silica gel C-200 $(200 \mathrm{mesh})$ was used for column chromatography. Merck Kieselgel $60 \mathrm{~F}_{254}$ was used for thin-layer chromatography (TLC), and spots were detected by

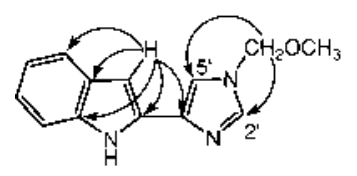

15

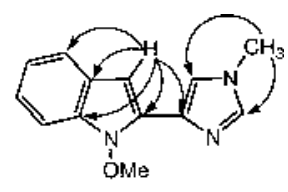

25
Fig. 1. Long-Range Correlations $\left({ }^{1} \mathrm{H}^{13} \mathrm{C}\right)$ in the HMBC Spectrum ultraviolet (UV) illumination and by spraying $1 \% \mathrm{Ce}\left(\mathrm{SO}_{4}\right)_{4}$ in $10 \% \mathrm{H}_{2} \mathrm{SO}_{4}$ followed by heating. The organic extract was dried over $\mathrm{Na}_{2} \mathrm{SO}_{4}$. THF was distilled from sodium-benzophenone under nitrogen atmosphere before use. Low pressure mercury lamp (EL-120) was used for irradiation.

4-(1-Methoxy-1H-indol-2-yl)-1-(methoxymethyl)- $1 H$-imidazole (14) $n$-BuLi in $n$-hexane $(2.5 \mathrm{~mol} / 1,0.5 \mathrm{ml}, 1.2 \mathrm{mmol})$ was added to the stirred solution of $11(147 \mathrm{mg}, 1 \mathrm{mmol})$ in THF at $-78^{\circ} \mathrm{C}$ under nitrogen atmosphere, and the mixture was stirred for $30 \mathrm{~min}$. Then, $\mathrm{Bu}_{3} \mathrm{SnCl}(488 \mathrm{mg}, 1.5 \mathrm{mmol})$ in THF was added dropwise, and the mixture was stirred at ambient temperature for $1 \mathrm{~h}$. The reaction mixture was worked up with $\mathrm{H}_{2} \mathrm{O}$, extracted with $\mathrm{Et}_{2} \mathrm{O}$, dried and concentrated. The residue was treated with $\mathbf{1 3}$ (280 mg, 1.2 $\mathrm{mmol})$ and $\mathrm{PdCl}_{2}\left(\mathrm{PPh}_{3}\right)_{2}(70 \mathrm{mg}, 0.1 \mathrm{mmol})$ in toluene $(10 \mathrm{ml})$, and the mixture was refluxed overnight. Then, the reaction mixture was concentrated in vacuo, and the residue was extracted with AcOEt, washed with brine, dried and concentrated. The residue was subjected to silica gel chromatograph (AcOEt) to give $123 \mathrm{mg}(48 \%)$ of $\mathbf{1 4}$ as an oil. IR $(\mathrm{KBr}) \mathrm{cm}^{-1}$ : 3110, 2936, $1505,1445,1397,1346,1218,1105,737 .{ }^{1} \mathrm{H}-\mathrm{NMR}\left(\mathrm{CDCl}_{3}, 300 \mathrm{MHz}\right) \delta$ : $3.34(3 \mathrm{H}, \mathrm{s}, \mathrm{O}-\mathrm{Me}), 3.98(3 \mathrm{H}, \mathrm{s}, \mathrm{N}-\mathrm{O}-\mathrm{Me}), 5.29\left(2 \mathrm{H}, \mathrm{s},-\mathrm{CH}_{2}-\right), 6.83(1 \mathrm{H}$, $\mathrm{s}$, indole $\mathrm{H}-3), 7.11(1 \mathrm{H}, \mathrm{t}, J=7.4 \mathrm{~Hz}$, indole $\mathrm{Ar}-\mathrm{H}), 7.23(1 \mathrm{H}, \mathrm{t}, J=7.2 \mathrm{~Hz}$, indole Ar-H), $7.43(1 \mathrm{H}, \mathrm{d}, J=8.0 \mathrm{~Hz}$, indole $\mathrm{Ar}-\mathrm{H}), 7.56(1 \mathrm{H}, \mathrm{d}, J=1.1 \mathrm{~Hz}$, imidazole H-5), $7.60(1 \mathrm{H}, \mathrm{d}, J=7.9 \mathrm{~Hz}$, indole Ar-H), $7.70(1 \mathrm{H}, \mathrm{d}, J=1.3 \mathrm{~Hz}$, imidazole H-2). ${ }^{13} \mathrm{C}-\mathrm{NMR}\left(\mathrm{CDCl}_{3}, 75.45 \mathrm{MHz}\right) \delta$ : 56.3, 64.1, 77.9, 96.2, $108.1,116.2,120.3,120.9,122.1,124.3,130.5,132.9,133.7,137.7$. HR-MS Calcd for $\mathrm{C}_{14} \mathrm{H}_{15} \mathrm{~N}_{3} \mathrm{O}_{2}: 257.1163$. Found: 257.1184. MS $m / z: 257\left(\mathrm{M}^{+}\right)$.

4-(1H-Indol-2-yl)-1-(methoxymethyl)-1 $\boldsymbol{H}$-imidazole (15) The mixture of $14(129 \mathrm{mg}, 0.5 \mathrm{mmol})$ and $\mathrm{Mg}(1.2 \mathrm{~g}, 50 \mathrm{mmol})$ in THF $(10 \mathrm{ml})-\mathrm{MeOH}$ $(20 \mathrm{ml})$ was refluxed under nitrogen atmosphere for $4 \mathrm{~h}$. Then, the reaction mixture was worked up with aq. $\mathrm{NH}_{4} \mathrm{Cl}$, extracted with $\mathrm{CH}_{2} \mathrm{Cl}_{2}$, washed with brine, dried and concentrated. The residue was recrystallized with $\mathrm{AcOEt}$ to give $85 \mathrm{mg}(75 \%)$ of 15 as white powder. $\mathrm{mp} 103-104^{\circ} \mathrm{C}$. IR $(\mathrm{KBr}) \mathrm{cm}^{-1}$ : 3196, 3100, 1343, 1321, 1107, 905, 784, 729. ${ }^{1} \mathrm{H}-\mathrm{NMR}\left(\mathrm{CDCl}_{3}, 500 \mathrm{MHz}\right)$ $\delta: 3.32(3 \mathrm{H}, \mathrm{s}, \mathrm{O}-\underline{\mathrm{Me}}), 5.23\left(2 \mathrm{H}, \mathrm{s},-\mathrm{CH}_{2}-\right), 6.66(1 \mathrm{H}, \mathrm{s}$, indole $\mathrm{H}-3), 7.08$ $(1 \mathrm{H}, \mathrm{t}, J=7.3 \mathrm{~Hz}$, indole Ar-H), $7.13(1 \mathrm{H}, \mathrm{t}, J=7.5 \mathrm{~Hz}$, indole Ar-H), 7.34 $(1 \mathrm{H}, \mathrm{d}, J=7.9 \mathrm{~Hz}$, indole Ar-H), $7.37(1 \mathrm{H}, \mathrm{d}, J=1.2 \mathrm{~Hz}$, imidazole H-5), 7.58 $(1 \mathrm{H}, \mathrm{d}, J=7.9 \mathrm{~Hz}$, indole Ar-H), $7.63(1 \mathrm{H}, \mathrm{d}, J=1.2 \mathrm{~Hz}$, imidazole $\mathrm{H}-2), 9.73$ $(1 \mathrm{H}, \mathrm{br}, \mathrm{N}-\mathrm{H}) .{ }^{13} \mathrm{C}-\mathrm{NMR}\left(\mathrm{CDCl}_{3}, 125.65 \mathrm{MHz}\right) \delta: 56.3,78.0,97.2,110.9$, 114.9, 119.8, 120.2, 121.6, 129.2, 132.2, 135.9, 136.4, 137.3. HR-MS Calcd for $\mathrm{C}_{13} \mathrm{H}_{13} \mathrm{~N}_{3} \mathrm{O}: 227.1058$. Found: 227.1087. MS $m / z: 227\left(\mathrm{M}^{+}\right)$.

3-Bromo-4-[2-(1-methoxymethyl-1H-imidazol-4-yl)-1H-indol-3yl]pyrrole-2,5-dione (19) Compound $15(114 \mathrm{mg}, 0.5 \mathrm{mmol})$ in THF (4 $\mathrm{ml}$ ) was added dropwise to the solution of $\mathrm{EtMgBr}$ prepared from $\mathrm{Mg}$ (24 $\mathrm{mg}, 1 \mathrm{mmol})$ and $\mathrm{EtBr}(218 \mathrm{mg}, 2 \mathrm{mmol})$ in THF $(2 \mathrm{ml})$, and the resulting solution was stirred at ambient temperature under nitrogen atmosphere for 30 min. Then, 17 (127 mg, $0.5 \mathrm{mmol})$ in THF $(2 \mathrm{ml})$ was added dropwise and the mixture was stirred overnight. The reaction mixture was worked up with aq. $\mathrm{NH}_{4} \mathrm{Cl}$, extracted with AcOEt, washed with brine, dried and concentrated. The residue was subjected to silica gel chromatograph (acetone: $\mathrm{CHCl}_{3}=1: 2$ ) to give $84 \mathrm{mg}(42 \%)$ of $\mathbf{1 9}$ as a red powder (from AcOEt- $n$ -
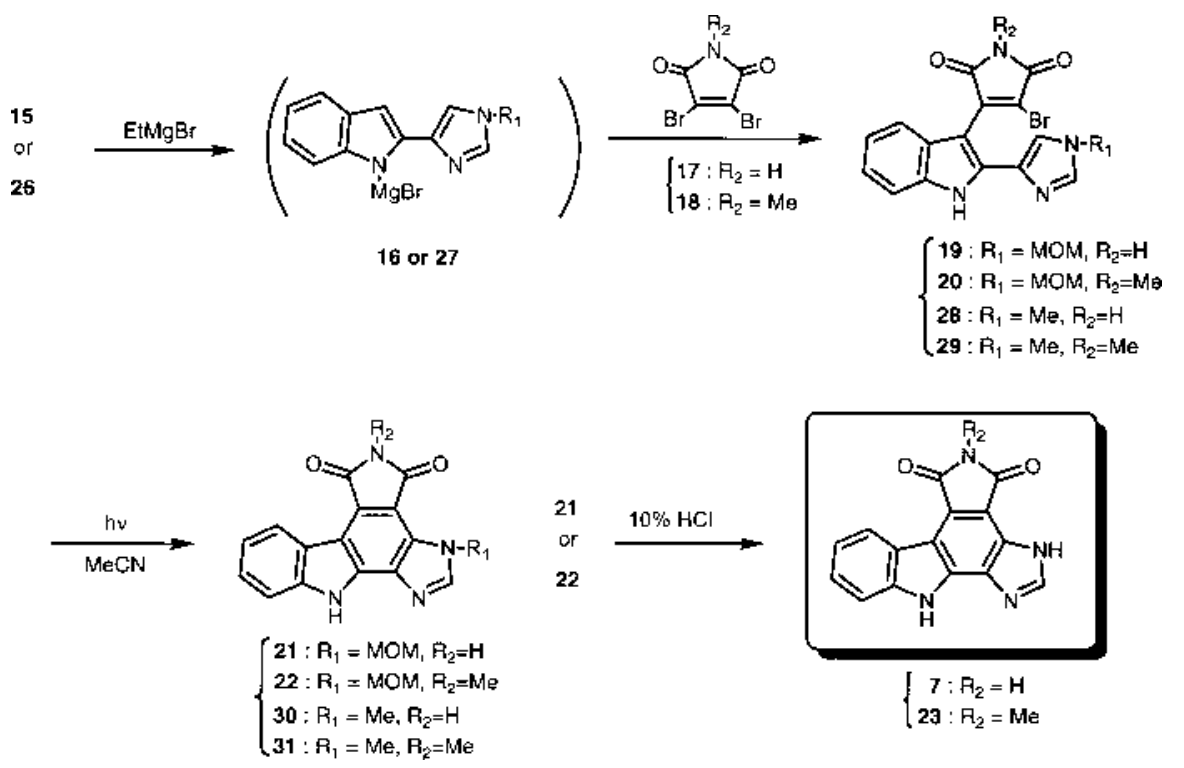

Chart 4 
hexane). $\mathrm{mp} 230^{\circ} \mathrm{C}$ (decomp.). IR (KBr) $\mathrm{cm}^{-1}: 3458,1765,1717,1625$, $1335,1110,1028,735 .{ }^{1} \mathrm{H}-\mathrm{NMR}\left(\mathrm{DMSO}-d_{6}, 300 \mathrm{MHz}\right) \delta: 3.23(3 \mathrm{H}, \mathrm{s}, \mathrm{O}$ $\underline{\mathrm{Me}}), 5.34\left(2 \mathrm{H}, \mathrm{s},-\mathrm{CH}_{2}-\right), 7.04(1 \mathrm{H}, \mathrm{t}, J=7.5 \mathrm{~Hz}$, indole $\mathrm{Ar}-\mathrm{H}), 7.14(1 \mathrm{H}, \mathrm{t}$, $J=7.5 \mathrm{~Hz}$, indole $\mathrm{Ar}-\mathrm{H}), 7.36(1 \mathrm{H}, \mathrm{d}, J=7.9 \mathrm{~Hz}$, indole $\mathrm{Ar}-\mathrm{H}), 7.44(1 \mathrm{H}, \mathrm{d}$, $J=8.1 \mathrm{~Hz}$, indole Ar-H), $7.66(1 \mathrm{H}, \mathrm{d}, J=1.3 \mathrm{~Hz}$, imidazole $\mathrm{H}-5), 7.90(1 \mathrm{H}, \mathrm{d}$, $J=1.3 \mathrm{~Hz}$, imidazole $\mathrm{H}-2), 11.24(1 \mathrm{H}, \mathrm{s}, \mathrm{CO}-\mathrm{NH}-\mathrm{CO}), 11.90(1 \mathrm{H}, \mathrm{s}, \mathrm{N}-\mathrm{H})$. ${ }^{13} \mathrm{C}-\mathrm{NMR}$ (DMSO- $\left.d_{6}, 75.45 \mathrm{MHz}\right) \delta: 50.6,76.9,98.2,111.6,118.7,119.7$, 119.8, 121.8, 122.6, 126.5, 133.6, 133.7, 135.9, 138.4, 140.7, 167.1, 169.2. HR-MS Calcd for $\mathrm{C}_{17} \mathrm{H}_{13}{ }^{79} \mathrm{BrN}_{4} \mathrm{O}_{3}: 400.0169$. Found: 400.0144. Calcd for $\mathrm{C}_{17} \mathrm{H}_{13}{ }^{81} \mathrm{BrN}_{4} \mathrm{O}_{3}$ : 402.0149. Found: 402.0103. MS $m / z: 400\left(\mathrm{M}^{+}\right), 402$ $\left(\mathrm{M}^{+}+2\right)$.

3-Bromo-4-[2-(1-methoxymethyl-1 $\boldsymbol{H}$-imidazol-4-yl)-1 $\boldsymbol{H}$-indol-3-yl]-1methylpyrrole-2,5-dione (20) Compound 15 (56 $\mathrm{mg}, 0.25 \mathrm{mmol})$ was treated with EtMgBr, followed by $\mathbf{1 8}(67 \mathrm{mg}, 0.25 \mathrm{mmol})$ as described for 19 to give $74 \mathrm{mg}(71 \%)$ of $\mathbf{2 0}$ as a red powder (from AcOEt- $n$-hexane). mp $210{ }^{\circ} \mathrm{C}$ (decomp.). IR (KBr) cm ${ }^{-1}$ : 3352, 3150, 2934, 1770, 1707, 1627, $1433,1380,1105,730 .{ }^{1} \mathrm{H}-\mathrm{NMR}\left(\mathrm{CDCl}_{3}, 300 \mathrm{MHz}\right) \delta: 3.19(3 \mathrm{H}, \mathrm{s}, \mathrm{N}-\mathrm{Me})$, $3.29(3 \mathrm{H}, \mathrm{s}, \mathrm{O}-\mathrm{Me}), 5.18\left(2 \mathrm{H}, \mathrm{s},-\mathrm{CH}_{2}-\right), 7.06(1 \mathrm{H}, \mathrm{d}, J=1.3 \mathrm{~Hz}$, imidazole $\mathrm{H}-5), 7.16(1 \mathrm{H}, \mathrm{t}, J=7.5 \mathrm{~Hz}$, indole $\mathrm{Ar}-\mathrm{H}), 7.22(1 \mathrm{H}, \mathrm{t}, J=7.5 \mathrm{~Hz}$, indole Ar-H), $7.39(1 \mathrm{H}, \mathrm{d}, J=7.5 \mathrm{~Hz}$, indole $\mathrm{Ar}-\mathrm{H}), 7.48(1 \mathrm{H}, \mathrm{d}, J=7.5 \mathrm{~Hz}$, indole Ar-H), $7.62(1 \mathrm{H}, \mathrm{d}, J=1.3 \mathrm{~Hz}$, imidazole $\mathrm{H}-2), 10.19(1 \mathrm{H}, \mathrm{br}, \mathrm{N}-\mathrm{H}) .{ }^{13} \mathrm{C}-$ NMR $\left(\mathrm{CDCl}_{3}, 75.45 \mathrm{MHz}\right) \delta: 24.9,56.4,78.0,99.2,111.5,118.1,120.5$, $120.9,122.3,123.0,127.1,133.1,134.2,135.6,137.2,139.9,166.3,168.6$. HR-MS Calcd for $\mathrm{C}_{18} \mathrm{H}_{15}{ }^{79} \mathrm{BrN}_{4} \mathrm{O}_{3}$ : 414.0325. Found: 414.0325. Calcd for $\mathrm{C}_{18} \mathrm{H}_{15}{ }^{81} \mathrm{BrN}_{4} \mathrm{O}_{3}: 416.0305$. Found: 416.0330. MS m/z: $414\left(\mathrm{M}^{+}\right), 416\left(\mathrm{M}^{+}+2\right)$.

17-(Methoxymethyl)granulatimide (21) The solution of 19 (30 mg, $0.075 \mathrm{mmol})$ in $\mathrm{MeCN}(6 \mathrm{ml})$ was irradiated with low-pressure mercury lamp $(60 \mathrm{~W})$ for $7 \mathrm{~h}$. Then, resulting solid material was filtered to give $20 \mathrm{mg}$ $(80 \%)$ of 21 as a yellow solid (from $\mathrm{MeOH}) . \mathrm{mp}>300^{\circ} \mathrm{C}$. IR $(\mathrm{KBr}) \mathrm{cm}^{-1}$ : 3256, 2948, 2716, 1740, 1705, 1324, 1221, 1104, 793, 734. ${ }^{1} \mathrm{H}-\mathrm{NMR}$ (DMSO- $\left.d_{6}, 300 \mathrm{MHz}\right) \delta: 3.26(3 \mathrm{H}, \mathrm{s}, \mathrm{O}-\mathrm{Me}), 6.15\left(2 \mathrm{H}, \mathrm{s},-\mathrm{CH}_{2}-\right), 7.31$ $(1 \mathrm{H}, \mathrm{t}, J=7.5 \mathrm{~Hz}$, indole $\mathrm{Ar}-\mathrm{H}), 7.50(1 \mathrm{H}, \mathrm{t}, J=7.5 \mathrm{~Hz}$, indole Ar-H), 7.62 $(1 \mathrm{H}, \mathrm{d}, J=8.1 \mathrm{~Hz}$, indole Ar-H), $8.70(1 \mathrm{H}, \mathrm{s}$, imidazole $\mathrm{H}-2), 8.95(1 \mathrm{H}, \mathrm{d}$, $J=8.1 \mathrm{~Hz}$, indole Ar-H), $11.09(1 \mathrm{H}, \mathrm{s}, \mathrm{CO}-\mathrm{NH}-\mathrm{CO}), 12.65(1 \mathrm{H}, \mathrm{s}, \mathrm{N}-\mathrm{H})$. ${ }^{13} \mathrm{C}$-NMR (DMSO- $\left.d_{6}, 75.45 \mathrm{MHz}\right) \delta: 55.2,77.5,109.5,111.7,113.6,120.2$, $121.2,124.1,124.2,126.5,127.5,133.6,135.7,140.7,147.0,169.0,170.6$. HR-MS Calcd for $\mathrm{C}_{17} \mathrm{H}_{12} \mathrm{~N}_{4} \mathrm{O}_{3}$ : 320.0909. Found: 320.0893. MS $m / z: 320$ $\left(\mathrm{M}^{+}\right)$.

10-Methyl-17-(methoxymethyl)granulatimide (22) Compound 20 (42 $\mathrm{mg}, 0.1 \mathrm{mmol})$ was irradiated as described for $\mathbf{2 1}$ to give $32 \mathrm{mg}(96 \%)$ of $\mathbf{2 2}$ as a yellow powder (from $\mathrm{MeOH}) . \mathrm{mp}>300^{\circ} \mathrm{C}$. IR $(\mathrm{KBr}) \mathrm{cm}^{-1}: 3106,1758$, $1694,1594,1376,1252,1114,733 .{ }^{1} \mathrm{H}-\mathrm{NMR}$ (DMSO- $\left.d_{6}, 300 \mathrm{MHz}\right) \delta: 3.05$ $(3 \mathrm{H}, \mathrm{s}, \mathrm{N}-\underline{\mathrm{Me}}), 3.25(3 \mathrm{H}, \mathrm{s}, \mathrm{O}-\underline{\mathrm{Me}}), 6.05\left(2 \mathrm{H}, \mathrm{s},-\mathrm{CH}_{2}-\right), 7.29(1 \mathrm{H}, \mathrm{t}, J=7.0$ $\mathrm{Hz}$, indole $\mathrm{Ar}-\mathrm{H}), 7.50(1 \mathrm{H}, \mathrm{t}, J=7.0 \mathrm{~Hz}$, indole $\mathrm{Ar}-\mathrm{H}), 7.61(1 \mathrm{H}, \mathrm{d}, J=8.1$ $\mathrm{Hz}$, indole Ar- $\mathrm{H}), 8.66(1 \mathrm{H}, \mathrm{s}$, imidazole $\mathrm{H}-2), 8.88(1 \mathrm{H}, \mathrm{d}, J=7.9 \mathrm{~Hz}$, indole Ar-H), $12.58\left(1 \mathrm{H}\right.$, br, N-H). ${ }^{13} \mathrm{C}-\mathrm{NMR}$ (DMSO- $\left.d_{6}, 75.45 \mathrm{MHz}\right) \delta: 23.5$, $55.2,77.3,108.3,111.7,113.7,120.2,121.0,122.9,124.0,126.5,127.3$, 133.2, 135.4, 140.7, 146.9, 167.4, 169.0. HR-MS Calcd for $\mathrm{C}_{18} \mathrm{H}_{14} \mathrm{~N}_{4} \mathrm{O}_{3}$ : 334.1065. Found: 334.1053 . MS $m / z: 334\left(\mathrm{M}^{+}\right)$.

Granulatimide (7) The solution of $21(16 \mathrm{mg}, 0.05 \mathrm{mmol})$ in $10 \%$ aq. $\mathrm{HCl}(2 \mathrm{ml})$ was heated at $100^{\circ} \mathrm{C}$ for $2 \mathrm{~h}$. After cooling, the reaction mixture was basisity with aq. $\mathrm{NaHCO}_{3}$. The resulting solid was corrected to give 9.9 $\mathrm{mg}(72 \%)$ of 7 as a yellow solid (from $\mathrm{MeOH}$ ).

10-Methylgranulatimide (23) Compound $22(17 \mathrm{mg}, 0.05 \mathrm{mmol})$ was treated with $10 \%$ aq. $\mathrm{HCl}(10 \mathrm{ml})$ for $16 \mathrm{~h}$ as described for 7 to give $13.3 \mathrm{mg}$ $(92 \%)$ of 23 as a yellow solid (from $\mathrm{MeOH}) . \mathrm{mp}>300^{\circ} \mathrm{C}$. IR $(\mathrm{KBr}) \mathrm{cm}^{-1}$ : $3306,1749,1690,1378,804,736 .{ }^{1} \mathrm{H}-\mathrm{NMR}$ (DMSO-d, $\left.300 \mathrm{MHz}\right) \delta: 3.12$ $(3 \mathrm{H}, \mathrm{s}, \mathrm{N}-\underline{\mathrm{Me}}), 7.30(1 \mathrm{H}, \mathrm{t}, J=7.9 \mathrm{~Hz}$, indole $\mathrm{Ar}-\mathrm{H}), 7.49(1 \mathrm{H}, \mathrm{t}, J=7.5 \mathrm{~Hz}$, indole $\mathrm{Ar}-\mathrm{H}), 7.62(1 \mathrm{H}, \mathrm{d}, J=8.1 \mathrm{~Hz}$, indole $\mathrm{Ar}-\mathrm{H}), 8.52(1 \mathrm{H}, \mathrm{s}$, imidazole $\mathrm{H}-2), 8.90(1 \mathrm{H}, \mathrm{d}, J=7.7 \mathrm{~Hz}$, indole $\mathrm{Ar}-\mathrm{H}), 12.54(1 \mathrm{H}, \mathrm{br}$, indole $\mathrm{N}-\mathrm{H})$, $13.56(1 \mathrm{H}$, br, imidazole $\mathrm{N}-\mathrm{H}) .{ }^{13} \mathrm{C}-\mathrm{NMR}$ (DMSO- $\left.d_{6}, 75.45 \mathrm{MHz}\right) \delta: 23.5$, $108.7,111.7,113.2,120.1,121.3,121.8,123.7,126.2,135.1,140.5,144.6$, 168.1, 169.6. HR-MS Calcd for $\mathrm{C}_{16} \mathrm{H}_{10} \mathrm{~N}_{4} \mathrm{O}_{2}$ : 290.0803. Found: 290.0783 . MS $m / z: 290\left(\mathrm{M}^{+}\right)$.

4-(1-Methoxy-1H-indol-2-yl)-1-methyl-1 $\boldsymbol{H}$-imidazole (25) $n$-BuLi in $n$-hexane $(2.5 \mathrm{~mol} / 1,2.0 \mathrm{ml}, 4.8 \mathrm{mmol})$ was added to the stirred solution of $11(592 \mathrm{mg}, 4 \mathrm{mmol})$ in $\mathrm{THF}$ at $-78^{\circ} \mathrm{C}$ under nitrogen atmosphere, and the mixture was stirred for $30 \mathrm{~min}$. Then, $\mathrm{Bu}_{3} \mathrm{SnCl}(1.96 \mathrm{~g}, 6.0 \mathrm{mmol})$ in $\mathrm{THF}$ was added dropwise, and the mixture was stirred at ambient temperature for $1 \mathrm{~h}$. The reaction mixture was worked up with $\mathrm{H}_{2} \mathrm{O}$, extracted with $\mathrm{Et}_{2} \mathrm{O}$, dried and concentrated. The residue was treated with $24(1.0 \mathrm{~g}, 4.8 \mathrm{mmol})$ and $\mathrm{PdCl}_{2}\left(\mathrm{PPh}_{3}\right)_{2}(280 \mathrm{mg}, 0.4 \mathrm{mmol})$ in toluene $(80 \mathrm{ml})$, and the mixture was refluxed overnight. Then, the reaction mixture was concentrated in vacuo, and the residue was extracted with AcOEt, washed with brine, dried and concentrated. The residue was subjected to silica gel chromatograph (AcOEt) to give $529 \mathrm{mg}(58 \%)$ of $\mathbf{2 5}$ as white powder (from AcOEt- $n$ hexane). $\mathrm{mp} 91-92{ }^{\circ} \mathrm{C}$. IR $(\mathrm{KBr}) \mathrm{cm}^{-1}: 3114,2922,1641,1517,1462$, $1416,1231,1206,1101,937,612 .{ }^{1} \mathrm{H}-\mathrm{NMR}\left(\mathrm{CDCl}_{3}, 500 \mathrm{MHz}\right) \delta: 3.74(3 \mathrm{H}$, $\mathrm{s}, \mathrm{N}-\underline{\mathrm{Me}}), 3.96(3 \mathrm{H}, \mathrm{s}, \mathrm{O}-\underline{\mathrm{Me}}), 6.78(1 \mathrm{H}, \mathrm{s}$, indole $\mathrm{H}-3), 7.10(1 \mathrm{H}, \mathrm{t}, J=7.9$ $\mathrm{Hz}$, indole $\mathrm{Ar}-\mathrm{H}), 7.21(1 \mathrm{H}, \mathrm{t}, J=7.9 \mathrm{~Hz}$, indole $\mathrm{Ar}-\mathrm{H}), 7.39(1 \mathrm{H}$, s, imidazole H-5), 7.42 (1H, d, $J=7.9 \mathrm{~Hz}$, indole Ar-H), 7.51 (1H, s, imidazole H-2), $7.58\left(1 \mathrm{H}, \mathrm{d}, J=7.9 \mathrm{~Hz}\right.$, indole Ar-H). ${ }^{13} \mathrm{C}-\mathrm{NMR}\left(\mathrm{CDCl}_{3}, 125.65 \mathrm{MHz}\right) \delta$ : $33.5,64.1,95.7,108.1,117.8,120.3,120.8,121.9,124.5,131.0,132.8$, 133.1, 138.1. HR-MS Calcd for $\mathrm{C}_{13} \mathrm{H}_{13} \mathrm{~N}_{3} \mathrm{O}: 227.1058$. Found: 227.1084. MS $m / z: 227\left(\mathrm{M}^{+}\right)$.

4-(1H-Indol-2-yl)-1-methyl-1H-imidazole (26) The mixture of 25 (454 $\mathrm{mg}, 2 \mathrm{mmol})$ and $\mathrm{Mg}(4.8 \mathrm{~g}, 200 \mathrm{mmol})$ in THF $(40 \mathrm{ml})-\mathrm{MeOH}(80 \mathrm{ml})$ was refluxed under nitrogen atmosphere for $5 \mathrm{~h}$. Then, the reaction mixture was worked up with aq. $\mathrm{NH}_{4} \mathrm{Cl}$, extracted with $\mathrm{CH}_{2} \mathrm{Cl}_{2}$, washed with brine, dried and concentrated. The residue was recrystallized from AcOEt to give 365 $\mathrm{mg}(93 \%)$ of 26 as white powder. mp $222-224^{\circ} \mathrm{C}$. IR $(\mathrm{KBr}) \mathrm{cm}^{-1}: 3144$, $3100,1522,1414,1335,1292,788,736 .{ }^{1} \mathrm{H}-\mathrm{NMR}$ (DMSO- $\left.d_{6}, 300 \mathrm{MHz}\right) \delta$ : $3.70(3 \mathrm{H}, \mathrm{s}, \mathrm{N}-\underline{\mathrm{Me}}), 6.56(1 \mathrm{H}, \mathrm{s}$, indole $\mathrm{H}-3), 6.93(1 \mathrm{H}, \mathrm{t}, J=7.5 \mathrm{~Hz}$, indole Ar-H), $7.01(1 \mathrm{H}, \mathrm{t}, J=7.4 \mathrm{~Hz}$, indole $\mathrm{Ar}-\mathrm{H}), 7.35(1 \mathrm{H}, \mathrm{d}, J=7.9 \mathrm{~Hz}$, indole Ar-H), $7.45(1 \mathrm{H}, \mathrm{d}, J=7.7 \mathrm{~Hz}$, indole $\mathrm{Ar}-\mathrm{H}), 7.52(1 \mathrm{H}, \mathrm{s}$, imidazole H-5), $7.67(1 \mathrm{H}, \mathrm{s}$, imidazole $\mathrm{H}-2), 11.24(1 \mathrm{H}, \mathrm{s}, \mathrm{N}-\mathrm{H}) .{ }^{13} \mathrm{C}-\mathrm{NMR}$ (DMSO-d $d_{6}$, 75.45 MHz): 33.1, 96.0, 111.0, 117.1, 118.9, 119.4, 120.4, 128.7, 133.9, 134.9, 136.2, 138.3. HR-MS Calcd for $\mathrm{C}_{12} \mathrm{H}_{11} \mathrm{~N}_{3}$ : 197.0952. Found: 197.0979. MS $m / z: 197\left(\mathrm{M}^{+}\right)$.

3-Bromo-4-[2-(1-methyl-1H-imidazol-4-yl)-1H-indol-3-yl]pyrrole-2,5dione (28) Compound 26 (197 mg, $1 \mathrm{mmol})$ was treated with $\mathrm{EtMgBr}$, followed by 17 (255 mg, $1 \mathrm{mmol}$ ) as described for 19 to give $158 \mathrm{mg}(43 \%)$ of 28 as a red powder (from AcOEt- $n$-hexane). mp $240{ }^{\circ} \mathrm{C}$ (decomp.). IR (KBr) $\mathrm{cm}^{-1}$ : 3332, 1710, 1620, 1435, 1340, 1037, 618. ${ }^{1} \mathrm{H}-\mathrm{NMR}$ (DMSO$\left.d_{6}, 300 \mathrm{MHz}\right) \delta: 3.75(3 \mathrm{H}, \mathrm{s}, \mathrm{N}-\underline{\mathrm{Me}}), 7.09(1 \mathrm{H}, \mathrm{t}, J=7.5 \mathrm{~Hz}$, indole Ar-H), $7.18(1 \mathrm{H}, \mathrm{t}, J=7.5 \mathrm{~Hz}$, indole Ar-H), $7.39(1 \mathrm{H}, \mathrm{d}, J=7.9 \mathrm{~Hz}$, indole Ar-H), $7.49(1 \mathrm{H}, \mathrm{d}, J=7.9 \mathrm{~Hz}$, indole Ar-H), $7.55(1 \mathrm{H}, \mathrm{d}, J=1.1 \mathrm{~Hz}$, imidazole $\mathrm{H}-5)$, $7.73(1 \mathrm{H}, \mathrm{d}, J=0.9 \mathrm{~Hz}$, imidazole $\mathrm{H}-2), 11.29(1 \mathrm{H}, \mathrm{s}, \mathrm{CO}-\mathrm{NH}-\mathrm{CO}), 11.88$ $(1 \mathrm{H}, \mathrm{s}, \mathrm{N}-\mathrm{H}) .{ }^{13} \mathrm{C}-\mathrm{NMR}$ (DMSO- $\left.d_{6}, 75.45 \mathrm{MHz}\right) \delta: 33.1,97.6,111.5,119.5$, $119.7(\times 2), 121.6,122.6,126.6,133.1,134.1,135.8,138.4,140.9,167.1$, 169.2. HR-MS $m / z$ : Calcd for $\mathrm{C}_{16} \mathrm{H}_{11}{ }^{79} \mathrm{BrN}_{4} \mathrm{O}_{2}$ : 370.0063 . Found: 370.0066 . Calcd for $\mathrm{C}_{16} \mathrm{H}_{11}{ }^{81} \mathrm{BrN}_{4} \mathrm{O}_{2}$ : 372.0043. Found: 372.0068. MS $m / z$ : $370\left(\mathrm{M}^{+}\right)$, $372\left(\mathrm{M}^{+}+2\right)$.

3-Bromo-4-[2-(1-methyl-1 $\boldsymbol{H}$-imidazol-4-yl)-1 $\boldsymbol{H}$-indol-3-yl]-1-methylpyrrole-2,5-dione (29) Compound 26 (49 $\mathrm{mg}, 0.25 \mathrm{mmol})$ was treated with $\mathrm{EtMgBr}$, followed by $\mathbf{1 8}(67 \mathrm{mg}, 0.25 \mathrm{mmol})$ as described for 19 to give $65 \mathrm{mg}(68 \%)$ of 29 as a red powder (from AcOEt- $n$-hexane). $\mathrm{mp}>300^{\circ} \mathrm{C}$. IR (KBr) $\mathrm{cm}^{-1}: 3328,1773,1708,1630,1438,1380,840,810,736 .{ }^{1} \mathrm{H}-$ NMR (DMSO- $\left.d_{6}, 300 \mathrm{MHz}\right) \delta: 3.01(3 \mathrm{H}, \mathrm{s}, \mathrm{CO}-\mathrm{N}-\mathrm{Me}), 3.68(3 \mathrm{H}, \mathrm{s}$, $\mathrm{N}-\mathrm{Me}), 7.03(1 \mathrm{H}, \mathrm{t}, J=7.0 \mathrm{~Hz}$, indole $\mathrm{Ar}-\mathrm{H}), 7.13(1 \mathrm{H}, \mathrm{t}, J=7.0 \mathrm{~Hz}$, indole Ar-H), $7.35(1 \mathrm{H}, \mathrm{d}, J=7.9 \mathrm{~Hz}$, indole Ar-H), $7.44(1 \mathrm{H}, \mathrm{d}, J=7.9 \mathrm{~Hz}$, indole Ar-H), $7.52(1 \mathrm{H}, \mathrm{d}, J=1.3 \mathrm{~Hz}$, imidazole H-5), $7.68(1 \mathrm{H}, \mathrm{d}, J=0.9 \mathrm{~Hz}$, imidazole H-2), $11.88(1 \mathrm{H}, \mathrm{s}, \mathrm{N}-\mathrm{H}) .{ }^{13} \mathrm{C}-\mathrm{NMR}$ (DMSO-d, $\left.75.45 \mathrm{MHz}\right) \delta: 24.5$, $33.1,97.5,111.5,119.6,119.7,119.9,121.6,121.8,126.6,132.9,134.2$, 135.8, 138.3, 140.2, 166.2, 168.2. HR-MS Calcd for $\mathrm{C}_{17} \mathrm{H}_{13}{ }^{79} \mathrm{BrN}_{4} \mathrm{O}_{2}$ : 384.0220. Found: 384.0259. Calcd for $\mathrm{C}_{17} \mathrm{H}_{13}{ }^{81} \mathrm{BrN}_{4} \mathrm{O}_{2}$ : 386.0199. Found: 386.0244. MS $m / z: 384\left(\mathrm{M}^{+}\right), 386\left(\mathrm{M}^{+}+2\right)$.

17-Methylgranulatimide (30) Compound $28(28 \mathrm{mg}, 0.075 \mathrm{mmol})$ was irradiated as described for $\mathbf{2 1}$ to give $11 \mathrm{mg}(50 \%)$ of $\mathbf{3 0}$ as a yellow powder (from $\mathrm{MeOH}$ ).

10,17-Dimethylgranulatimide (31) Compound 29 (39 mg, $0.1 \mathrm{mmol})$ was irradiated as described for $\mathbf{2 1}$ to give $21 \mathrm{mg}(\mathbf{7 0 \% )}$ of $\mathbf{3 1}$ as a yellow powder (from $\mathrm{MeOH}) . \mathrm{mp}>300^{\circ} \mathrm{C}$. IR $(\mathrm{KBr}) \mathrm{cm}^{-1}: 3122,3064,1756$, $1701,1431,1381,1255,800,734 .{ }^{1} \mathrm{H}-\mathrm{NMR}$ (DMSO- $\left.d_{6}, 300 \mathrm{MHz}\right) \delta: 3.08$ $(3 \mathrm{H}, \mathrm{s}, \mathrm{CO}-\mathrm{N}-\underline{\mathrm{Me}}), 4.28(3 \mathrm{H}, \mathrm{s}, \mathrm{N}-\underline{\mathrm{Me}}), 7.27(1 \mathrm{H}, \mathrm{t}, J=7.4 \mathrm{~Hz}$, indole Ar$\mathrm{H}), 7.49(1 \mathrm{H}, \mathrm{t}, J=7.4 \mathrm{~Hz}$, indole $\mathrm{Ar}-\mathrm{H}), 7.61(1 \mathrm{H}, \mathrm{d}, J=7.9 \mathrm{~Hz}$, indole Ar$\mathrm{H}), 8.52(1 \mathrm{H}, \mathrm{s}$, imidazole $\mathrm{H}-2), 8.91(1 \mathrm{H}, \mathrm{d}, J=7.7 \mathrm{~Hz}$, indole Ar-H), 12.55 $\left(1 \mathrm{H}\right.$, br, N-H). ${ }^{13} \mathrm{C}-\mathrm{NMR}$ (DMSO-d, $\left.75.45 \mathrm{MHz}\right) \delta: 23.0,34.5,108.3$, $111.2,113.0,119.7,121.0,122.3,123.6,126.0,128.1,132.8,135.1,140.4$, 146.5, 167.2, 168.8. HR-MS Calcd for $\mathrm{C}_{17} \mathrm{H}_{12} \mathrm{~N}_{4} \mathrm{O}_{2}$ : 304.0959. Found: 304.0941. MS $m / z: 304\left(\mathrm{M}^{+}\right)$.

\section{References}

1) Pindur U., Kim Y.-S., Mehrabani F., Curr. Med. Chem., 6, 29-69 (1999).

2) Prudhomme M., Curr. Med. Chem., 7, 1189-1212 (2000).

3) Schlegel R., Pardee A. B., Science., 232, 1264-1266 (1986).

4) Downes C. S., Musk S. R. R., Watson J. V., Johnson R. T., J. Cell Biol., 
110, 1855-1859 (1990).

5) Sarkaria J. N., Busby E. C., Tibbetts R. S., Roos P., Taya Y., Karnitz L. M., Abraham R. T., Cancer Res., 59, 4375-4382 (1999).

6) Berlinck R. G. S., Britton R., Piers E., Lim L. Roberge M., da Rocha R. M., Andersen R. J., J. Org. Chem., 63, 9850-9856 (1998).

7) Roberg M., Berlinck R. G. S., Xu L., Anderson H. J., Lim L. Y., Curman D., Stringer C. M., Friend S. H., Davies P., Vincent I., Haggarty S. J., Kelly M. T., Britton R., Piers E., Andersen R. J., Cancer Res., 58, 5701-5706 (1998).

8) Vervoort H. C., Fenical W., Keifer P. A., J. Nat. Prod., 62, 389-391 (1999).

9) Britton R., de Oliveria J. H. H. L., Andersen R. J., Berlinck R. G. S., J.
Nat. Prod., 64, 254-255 (2001).

10) Piers E., Britton R., Andersen R. J., J. Org. Chem., 65, 530-535 (2000).

11) Terpin A., Winklhofer C., Schumann S., Steglich W., Tetrahedron, 54, 1745-1752 (1998).

12) Murase M., Watanabe K., Kurihara T., Tobinaga S., Chem. Pharm. Bull., 46, 889-892 (1998).

13) Murase M., Watanabe K., Yoshida T., Tobinaga S., Chem. Pharm. Bull., 48, 81-84 (2000).

14) Lovely C. J., Du H., Dias H. V. R., Org. Lett., 3, 1391-1322 (2001).

15) Iddon B., Lim B. L., J. Chem. Soc., Perkin Trans. 1, 1983, 735-739.

16) Somei M., Nakagawa K., Heterocycles, 39, 31-34 (1994). 